\title{
Learning Management Based on Language Teaching for Communication Combined With Grouping Techniques to Develop Chinese Speaking Skills for Everyday Use of Secondary 4 Students
}

\author{
Pittayarat Yamprayoon, Rossarin Jermtaisong* \\ Faculty of Technical Education \\ Rajamangala University of Technology Thanyaburi \\ Pathumthani province, Thailand \\ Pittayarat_y@mail.rmutt.ac.th, *Rossarin_j@rmutt.ac.th
}

\begin{abstract}
Nowadays, language learning focuses on students' ability in real life communication so that students can be in society properly and appropriately. Language learning can be started from the very basic level and gradually increased to the complexity both in depth and width according to the age and level of the learners. Therefore, teachers must understand the curriculum and be able to design learning management focusing on student-centered instruction. This aims to enable learners to use the language in real situations including speaking, listening, reading and writing skills. The main purposes of this research were 1) To compare Chinese communication skills for everyday use of students before and after studying through traditional learning management, 2) To compare Chinese communication skills for everyday use of students before and after studying through language instruction combined with grouping techniques, 3) To compare Chinese speaking communication skills for everyday use of students who studied through traditional learning management and the newly created method. Research sample was 50 students, selected by cluster random sampling, of Pratandongrungwittayakarn School, The Secondary Educational Service Area 8. Research tools were 1) plans for traditional instruction, 2) Learning management plan based on language for communication instruction combined with grouping techniques, and 3) A Chinese speaking skill evaluation form for communication. The research result revealed that 1) Chinese communication skills for everyday use, before and after studying, of secondary 4 (grade 10) students who studied through the traditional learning management., 2) Chinese communication skills for everyday use, before and after studying, of students who studied through language for communication instruction combined with grouping techniques were statistically significant difference at the level of $\mathbf{0 . 0 5}$, and 3 ) the after study Chinese communication skills for everyday use of students who studied through language instruction for communication combined with grouping techniques was higher than those who studied through the traditional learning management.
\end{abstract}

Keywords-Chinese speaking skills, language instruction for communication, grouping technique

\section{INTRODUCTION}

In the present society, The People's Republic of China plays an important role in economic development not only in the ASEAN region, but also in various regions of the world. And this is likely to continue to expand its role in the international community. As we may know, Chinese has been spoken by almost 2 billion people around the world. It is the second after the English language and is one of the major languages of the United Nations. Hence, Chinese is a very important and essential foreign language for communication, to build up social and economic cooperation, politics and education. Thailand and China have good diplomatic relations for a very long time. The two countries have agreed with joint investments in businesses and continuing education management. [1]. This also resulted in the widespread of the Chinese instruction and is also considered another foreign language courses offered in public and private educational institutions. In the provision of basic education according to the core curriculum of basic education, $2551 \mathrm{BE}$, Chinese was also included in the foreign language learning subjects. This aims to develop learners to skills and ability to communicate in basic Chinese effectively and have a good attitude towards the Chinese language [2]. In Chinese language learning management, teachers should be aware and understand how to outline Chinese instruction correctly so that students learn how to acquire and use it effectively for real communication in daily life [3].

Comparing all four language skills: listening, speaking, reading and writing, it was found that speaking is basically a very important and essential skill of all. This is because speaking is used to communicate in everyday life and is an important process for exchanging information, conveying thoughts and understanding including feelings for the audience to know and understand the purpose of the speaker [4]. In maximum benefit of communication, the speaker must have a 
purpose in speaking. Therefore, ability to convey meaning to the audience along with the interaction between the speaker and the audience are considered important since they cause communication more efficient and effective. In Chinese communication instruction, pronunciation is an importantly elementary skill. If the learners do not pronounce correctly, it would lead to the misunderstanding and miscommunicating. Therefore, learning Chinese must focus on pronunciation since it is an important factor that directly affects the future of learners. If the teacher is good at pronunciation skills, it will benefit the students and brings about good communication skills in the future. On the contrary, if the students cannot pronounce the Chinese language correctly, this would lead to a great misunderstanding in communication and results in hatred and detestation at the end. Therefore, whether a person will learn Chinese well or not depends on the beginning of phonetics [5]. Even though the development of Chinese speaking skills has been conducted in Thailand for a long time, the related researches revealed that it was not as successful as expected. More and more learners were unable to deploy what they have studied effectively [6] and academic performance was not as good as it should be, especially in speaking skills [7]. This may be due to the focus on teaching and learning purposes-writing and reading-- not on the communication in everyday life. [8]. Moreover, teaching methods cannot meet students' needs. Teachers lack teaching techniques to attract students' intention to concentrate and be interested in learning Chinese. Generally, Chinese instruction was stuck in a very traditional way of memorization, reading and writing without incentivizing to be applied in real life [7]. The development of teaching and teach management to develop speaking language skills emphasizing communication in everyday life is therefore important. Communicative Language Teaching (CLT) is one of the guidelines in the language teaching management which emphasizes on communication and focuses on learners to be able to use the language in real situations. Teachers encourage and help learners to express themselves in both speaking and writing skills including allowing students to understand the text they read or understand what they hear [9]. They focus on the fluency but never neglect on accuracy of the language. Activities to practice the language use that is as close to the real situation as possible are included such as situational dialogs, role plays, and [10].

In addition, the combination of teaching methods or techniques into language teaching for communication to improve learning outcomes of Chinese language showed better result than a single technique solely [11]. This combination led to a group process which is one of the techniques that divides learners into small groups to support and allow students in the group to work together. The grouping technique helps support students use the language correctly, fluently and appropriately. Students should have the opportunity to acquire as much language skills as possible. Practicing may be in pairs and in small groups so that they are able to practice their skills effectively. From studying related research papers on language teaching for communication and grouping techniques, the researcher would like to propose the learning management according to the language instruction for communication in order to develop Chinese speaking skills and grouping techniques to develop more effective Chinese speaking skills.

\section{RESEARCH OBJECTIVES}

- To compare Chinese communication skills for everyday use of secondary 4 (grade 10) students before and after traditional learning management.

- To compare Chinese communication skills for everyday use of secondary 4 (grade 10) students before and after language instruction for communication combined with grouping technique.

- To compare Chinese communication skills for everyday use of secondary 4 (grade 10) students before and after language instruction for communication combined with grouping technique and traditional learning management.

\section{MethodOLOGY}

This research was a Quasi-Experimental Research with the Pretest - Posttest Nonequivalent - Groups Design. Research sample was two classes (50 students), selected by cluster random sampling, Secondary 10 students studying at Pratandongrungwittayakarn School, Secondary Educational Service Area 8, academic year. The two classes (50 students) were divided into 2 groups as a control group and an experimental group. There were 25 students in each group. Variables in this research were independent variable and dependent variable. The independent variable consisted of 2 types of learning management: 1) Traditional learning management consisting of Introduction, Instruction, and Conclusion, 2) Language instruction for communication combined with grouping technique consisting of Presentation, Practice, and Production with the combination of pair speaking and single-dual- all together thinking techniques. Dependent variable was Chinese communication skills for everyday use of secondary 4 (grade 10) students. The contents deployed in the development of Chinese communication skills were from Basic Education Core Course, 2551 BE., Foreign Language Learning Subjects (3 year Chinese language course for grade $10-12$ ). The contents derived from the Chinese 2 course consisting of 4 units: 自我介绍？ (Self-Introduction)，你今年多大? (How old are you?) 你是哪国人? (What country are you from?) and 你喜欢吃什么? (What is your favorite food?) Research instruments were 1) traditional learning management plans, 2) language instruction for communication combined with grouping technique plans, and 3) A Chinese speaking for communication skill evaluation form based on Linder scale [12]. Mean, Standard Deviation, t-test (Dependent Samples) and t-test (Independent Samples) were used for data analysis. 


\section{RESEARCH ANALYSIS}

A. Data Analysis Results to Compare Chinese Communication Skills for Everyday Use of Students Before and After Traditional Learning Management

TABLE I. Data ANALYSis Results To Compare Chinese COMMUNICATION SKILls For EVERYdAY USE OF STUDENTS BEFORE AND AFTER TRADITIONAL LEARNING MANAGEMENT

\begin{tabular}{|l|c|c|c|c|c|c|}
\hline $\begin{array}{c}\text { conventional } \\
\text { learning } \\
\text { management }\end{array}$ & $\mathbf{n}$ & $\overline{\mathrm{X}}$ & \multicolumn{1}{|c|}{$\mathbf{S}$} & $\mathbf{t}$ & $\mathbf{d f}$ & Sig \\
\hline $\begin{array}{l}\text { before } \\
\text { after }\end{array}$ & 25 & 9.60 & 1.826 & $14.96^{*}$ & 24 & 0.000 \\
\hline
\end{tabular}

From table 1, it was found that the mean score of Chinese communication skills for everyday use of students after traditional learning management was at $\left(\mathrm{x}^{-}=14.76, \mathrm{~S}=3.218\right)$ which was higher than the before study $(x=9.60, S=1.826)$. This could be concluded that Chinese communication skills for everyday use of students after traditional learning management was higher than the before study statistically significant difference at the level of 0.05 .

\section{B. Data Analysis Results to Compare Chinese}

Communication Skills for Everyday Use Before and After Language Instruction for Communication Combined with Grouping Technique

TABLE II. DATA ANALYSIS RESUlts To COMPARE ChINESE COMMUNICATION SKILLS FOR EVERYDAY USE OF STUDENTS BEFORE AND AFTER LANGUAGE INSTRUCTION FOR COMMUNICATION COMBINED WITH GROUPING TECHNIQUE

\begin{tabular}{|l|c|c|c|c|c|c|}
\hline $\begin{array}{c}\text { language teaching } \\
\text { for communication } \\
\text { combined with } \\
\text { grouping techniques } \\
\text { as the learning } \\
\text { management }\end{array}$ & $\mathbf{n}$ & $\overline{\mathrm{X}}$ & $\mathbf{S}$ & $\mathbf{t}$ & $\mathbf{d f}$ & Sig \\
\hline $\begin{array}{l}\text { before } \\
\text { after }\end{array}$ & 25 & 11.44 & 1.530 & $18.08^{*}$ & 24 & 0.000 \\
\hline
\end{tabular}

From table 2, it was found that the mean score of Chinese communication skills for everyday use of students after language instruction for communication combined with grouping technique was at $\left(\mathrm{x}^{-}=18.48, \mathrm{~S}=2.931\right)$ which was higher than the before study $(\mathrm{x}=11.44, \mathrm{~S}=1.530)$. This could be concluded that Chinese communication skills for everyday use of students after language instruction for communication combined with grouping technique was higher than the before study statistically significant difference at the level of 0.05 .
C. Data Analysis Results to Compare Chinese Communication Skills for Everyday Use of Students Before and After Language Instruction for Communication Combined with Grouping Technique and Traditional Learning Management

TABLE III. DATA ANALYSIS RESULTS TO COMPARE CHINESE COMMUNICATION SKILLS FOR EVERYDAY USE OF STUDENTS BEFORE AND AFTER LANGUAGE INSTRUCTION FOR COMMUNICATION COMBINED WITH GROUPING TECHNIQUE AND TRADITIONAL LEARNING MANAGEMENT

\begin{tabular}{|l|c|c|c|c|c|c|}
\hline $\begin{array}{l}\text { Management of } \\
\text { learning after } \\
\text { classes }\end{array}$ & $\mathbf{n}$ & $\overline{\mathrm{X}}$ & $\mathbf{S}$ & $\mathbf{t}$ & $\mathbf{d f}$ & Sig \\
\hline $\begin{array}{l}\text { conventional } \\
\text { learning } \\
\text { management }\end{array}$ & 25 & 14.76 & 3.218 & $4.273^{*}$ & 48 & 0.000 \\
\cline { 1 - 1 } $\begin{array}{l}\text { learning management } \\
\text { based on the } \\
\text { language teaching for } \\
\text { communication } \\
\text { combined with } \\
\text { grouping techniques }\end{array}$ & 25 & 18.48 & 2.931 & & & \\
\hline
\end{tabular}

From table 3 , it was found that the mean score of Chinese communication skills for everyday use of secondary 4 (grade 10) students after language instruction for communication combined with grouping technique was at $\left(\mathrm{x}^{-}=18.48, \mathrm{~S}=\right.$ 2.931) which was higher than the traditional learning management $\left(\mathrm{x}^{-}=14.76, \mathrm{~S}=3.218\right)$. This could be concluded that Chinese communication skills for everyday use of secondary 4 (grade 10) students after study mean score was higher than the traditional learning management after study mean score statistically significant difference at the level of 0.05 .

\section{DISCUSSION}

- From the research results it was found that Chinese communication skills for everyday use of secondary 4 (grade 10) students after traditional learning management was higher than the before study statistically significant difference at the level of 0.05 . This may be caused by the traditional learning management characteristics. In such a method, the plans were set and conducted by teachers. Contents, discussions, questions, and teaching materials were from teachers solely [13]. This was in line with the Department of Curriculum and Instruction Development [14] which stated that in traditional learning management, a teacher was the one who prepared what he would teach from the textbooks including references. Then, he gathered all the stories and conveyed to students by lectures and discussions. Students may help summarize the story from studying. The traditional learning management process consisted of 3 steps: Introduction, Instruction, and Conclusion. Conducted a research on the Comparison of Academic Achievement and Attitudes towards English Language Learning of 
Primary 4 (grade 4) Students who have been managed to learn in accordance with the language teaching for communication through myths and folk tales and those who have been managed to learn in accordance with traditional learning management [15]. The result showed that the former had higher mean score in the after study than the before study. The result was also the same with the latter group.

- It was found from the research that the mean score of Chinese communication skills for everyday use of secondary 4 (grade 10) students after language instruction for communication combined with grouping technique was higher than the before study statistically significant difference at the level of 0.05 . This may be due to the mentioned learning manage focused on allowing students to do activities by themselves. Students were able to think, design what they wanted to learn, interacted and exchanged their learning knowledge by themselves including presented their own ideas to teachers. In addition, learning management by using language instruction for communication does not limit the students' ability on grammar only, but also encourages learners to develop all language skills [16]. Tanadda Chartwatcharapaisit, Sorapon Jirasawad, and Sompoj Panasawad )2018, 257-266) also supported that the English grammar achievement mean score of the primary 3 (grade 3 ) students after studying through the PPP method was at 0.05 statistically significant difference from the pre-study score.

- It was found that the after study mean score of Chinese communication skills for everyday use of secondary 4 (grade 10) students studied through language instruction for communication combined with grouping technique was higher than those studied through the traditional learning management statistically significant difference at the level of 0.05 . This showed that learning management based on language instruction for communication incorporated group techniques encouraged students to acquire language better than the traditional learning management. This may be because language is not merely a grammatical system made up of sound, structure and vocabulary, but language is also a system used to communicate or convey meaning. This is in line with the management of learning according to the language instruction for basic communication which derived from the concept that "Language is a tool of communication and the goal of language teaching is to develop learners to have the ability to use language for communication by using language correctly according to people, places and occasions as well as knowledge in communication rules.'[17]. Moreover, the language achievement may result from the combination of grouping techniques in which students could practice communication skills simultaneously for both small groups and individuals. This would encourage the learners to develop their Chinese speaking skills. The language instruction for communication combined with grouping technique consisted of 3 steps: Presentation, Practice, and Production. Post-learning achievement of students studying through the English language learning management based on the dual speaking technique (Rally Robin) to improve the English language achievement of secondary 1 (grade 7) students showed higher academic achievement than the before study statistically significant difference at the level of 0.05 [18].

\section{SUGGESTIONS}

\section{A. Recommendations for Manipulation. In the language}

Instruction for communication combined with grouping techniques, teachers need to inform learners to understand the purpose of language learning and practice, what they are doing and what they are doing for. This is to make language learning meaningful to the learners. Giving the learners the impression that once they have learned, they can do something more and even more. The design of language activities should be similar to or look like everyday life activities. Providing many different kinds of practice will enable students to develop their ability to communicate and make use of their skills in the real situations. Teachers should encourage the students in designing learning activities which resulting in a variety of interesting activities. In addition, the native Chinese speaking style and/or native Chinese speakers should be introduced in classes so that students have examples of speaking and lead to application techniques into their real lives. This results in speaking confidence and assertive in speaking without fear and shyness.

\section{B. Recommendations for the Next Study}

- The study of learning management according to the concept of language instruction for communication combined with other instructional techniques should be studied to enhance Chinese speaking communication skills development.

- The language instruction for communication combined with grouping techniques should be studied to enhance Chinese reading, writing and listening skills for everyday use.

- The language instruction for communication combined with grouping techniques should be researched to enhance Chinese reading, writing and listening skills for other students' levels.

\section{CONCLUSION}

Communicative language teaching is an instructional management that focuses directly on the learners. The learning sequences have been clearly set into 3 steps as Presentation, Practice, and Production. Teacher plays a facilitator role for students to understand and develop the ability to acquire, develop, and use the language appropriately to people, time 
and opportunities. Grouping skills training and practicing will provide a good language experience. Therefore, language instruction for communication combined with grouping techniques make the learners more skillful and proficient in using the language for communication. Learners enable to improve their language skills effectively. However, the teaching and learning activities should be designed as close and/or similar to everyday life activities as possible. Providing many different kinds of training and practicing will lead to the students' ability in communication development. Students should have opportunities to participate in learning activities designing such as interesting role-play and simulation, games, and others things they want to do will result in better learning achievement. Furthermore, the freedom to choose interesting content, etc., is also one of the important factors affecting the success of teaching and learning.

\section{ACKNOWLEDGMENT}

This thesis has been accomplished with the great support of Asst. Prof. Dr. Rosarin Jermtaisong, Thesis Advisor, for her helpful and innumerable advices. The thesis is quite impossible without her great help.

Thanks to all experts who have devoted their time to consider the thesis and give feedback including checking and revising useful information. Thanks to the administrators, teachers and secondary 4 (grade 10) students of Pratandongrungwittayakarn School under the Regional Office of the Secondary Education Area 8 to cooperate in the thesis process. And thanks to all fellows and all staff who kindly give advice and help contact and coordinate well throughout the thesis.

In addition, thank you for Mr.Pooriphan Lertopat to advice and helpful suggestions for this research.

\section{REFERENCES}

[1] N. Adirek, "Development of Chinese communication skills by a responsive way with TPR gestures of Grade 4 students at Wat Khuyang School Office space Primary Education Kamphaeng Phet Khet 1," Panyapiwat Journal, vol. 7, no. 1, p. 150, 2015.

[2] Ministry of Education, 2008, p.211

[3] C. Kanchanang, Behavior of teaching in English. Sakon Nakhon Department of Curriculum and Teaching the Faculty of Education Sakon Nakhon Rajabhat Institute, 1999

[4] A. Sumitra, Methods of teaching English as a foreign language. Bangkok: Chulalongkorn University, 1997.
[5] K. Somporn, "Styles of learning foreign languages for students. Faculty of Arts, Dhurakij Pundit University," Suthipritat, vol. 30, no. 93, pp. 263-274, 2016

[6] A. Nuansri, "The Communicative Approach for Learning Chinese with the Total Physical Response (TPR) Method for the Grade 4 Students of Way Khu-yang, Kampheng phet Primary Education Area Office 1,' Panyapiwat Journal, no. 1, pp. 149-159, 2015.

[7] S. Warakorn, N. Phakorn, R. Waralee, R. Woratha, S. Woranat and C. Chutima, "A Study of Circumstances and Problems on Chinese Language Teaching and Learning in a Secondary School," Yala Province, vol. 2, no. 12, pp.126-136, 2017.

[8] T. Sureeporn, "Problems of teaching and learning Chinese in Thailand, The present era of vocational students," Pathumthan University Academic Journal, vol. 6, no. 2, p.199, 2014

[9] T. Monta, Development of English Listening and Speaking Skills of Grade Students.Grade 6 using activities for communication. (Master of Science in Education, Sakon Nakhon Rajabhat University), 2008

[10] A. Hasita Di Nam, The study of English listening-speaking ability of students.High School Grade 1 by Keith Johnson's conceptual language teaching method. (Master's Thesis, Thaksin University), 2009.

[11] K. Phongphan, Preliminary behavior adjustment. Bangkok: Departmen of Academic Guidance and Educational Psychology, Faculty of Education. Srinakharinwirot University, Prasarnmit, 1993.

[12] Y. Yorozu, M. Hirano, K. Oka, and Y. Tagawa, "Electron spectroscopy studies on magneto-optical media and plastic substrate interface," IEEE Transl. J. Magn. Japan, vol. 2, pp. 740-741, 1987.

[13] T. Jirachaya, A Comparison of Mattayam Suksa 3 students Achievement and Responsibility in learning Thai Through the Instructional Method Based on "STAD" and the Teacher's Manual. p.5, 2007.

[14] O. Nopnapa, A comparative study of matthayomsuksa 2 students' achievement of learning words and word functions in Thai language involving different teaching methods of the stad cooperative learning and the conventional. p.51, 2004.

[15] W. Pattama, "Comparison of academic achievement and attitudes towards learning.English language of the fourth grade students who have been managed according to the Teach language for communication using legends and folklore with traditional teaching," Journal Educational research Faculty of Education Srinakharinwirot University: vol. 9, no. 1, pp. 65-74, 2016.

[16] W. Littlewood, Communicative Language Teaching. Cambridge: Cambridge University Press, 1983.

[17] F. Finochiaro, M. Mary, and B. Christopher, "The Functional Nationa Approach: From Theory to Practice. New York, Oxford University Press.I.S. Jacobs and C.P. Bean, "Fine particles, thin films and exchange anisotropy," in Magnetism, vol. III, G.T. Rado and H. Suhl, Eds. New York: Academic, pp. 271-350, 1963,

[18] T. Kwanhathai, The effect of learning management by speaking techniques as A partner (Rally Robin) to improve English language achievement. For class Secondary Education Year 1. (Master of Education, Rajamangala University of Technology Thanyaburi), 2014. 